\title{
Impact of a Preparatory Year Programme on the Students of Health Professions Education Colleges Perception of students and faculty members
}

Ahmed Aldarmahi, ${ }^{1}$ Mohammed Al-Rabia, ${ }^{2}$ Fatimah Alserhani, ${ }^{3}$ Hanan Alzahrani, ${ }^{4}$ Norah Alrabia, ${ }^{5}$ Abdulaziz Alrubayyi, ${ }^{6}$ Hani Atwa ${ }^{7,8}$

ABSTRACT: Objectives: The preparatory year programme (PYP) at King Abdulaziz University, Jeddah, Saudi Arabia, is a one-year programme for students preparing for a full multi-year degree curriculum at a university. It offers a bridge between high-school and university-level studies of the students. This study aimed to evaluate the impact of the King Abdulaziz University PYP on students of the health professions education colleges from the viewpoints of the students and the faculty. Methods: This descriptive study was conducted between May 2019 and January 2020 at King Abdulaziz University, in Jeddah, Saudi Arabia and was based on data collected from both students and faculty to assess their perceptions. The data were collected from students through self-administered questionnaires and from faculty members through structured interviews. Descriptive statistics were used for analysis. Results: A total of 633 students responded to the questionnaire (response rate: 88.3\%), of which almost half agreed that the PYP made them self-confident and reinforced their discipline (49.2\% and 46.9\%, respectively). Less than two-thirds agreed that the preparatory year reinforced their sense of responsibility and helped them adapt to the university educational environment (60.6\% and 64.3\%, respectively). Conversely, more than half (58.5\%) disagreed that the preparatory year classes helped them select their majors as well as that the preparatory year prepared them for their major classes (57.2\%). A total of 24 faculty members who taught PYP students claimed that there should be careful consideration of the contents of the courses offered to the students in the preparatory year programme, especially the content related to the healthcare profession education. They argued that it is better to have a separate track in the PYP that includes subjects directly related to the study of health professions (such as molecular sciences, genetics, medical terminology, English for medical purposes, etc.). Conclusion: The impact of the PYP on students attending the health professions colleges was found to be weak as per the perceptions of both students and faculty members. In-depth studies are necessary for further investigation of this impact.

Keywords: Universities; Health Occupations; Undergraduate Medical Education; Curriculum; Saudi Arabia.

\section{ADVANCES IN KNOWLEDGE}

To the best of the authors' knowledge, this is the only study that explores the viewpoints of both students and faculty members and provides recommendations on the reform of that important preparatory programme for health professions education students.

\section{Application to Patient Care}

Understanding how the preparatory year programme is perceived by health professions education students is essential for improving such programmes. Preparation of those students to be competent healthcare providers starts from their first year in health professions education institutions, and a strong preparatory programme is expected to lead to better preparation of those graduates, and, eventually, better healthcare provision to the community.

$\mathrm{S}$ EVERAL HIGHER EDUCATION THEORIES AND cognitive models have tried to explain the factors involved in students' transition from high school to university and help this group adapt to a new academic context. ${ }^{1-5}$ The preparatory year aims to help students transition from the high school system of teaching/learning to that of a university, familiarise students with various academic disciplines at the university and integrate them into the university environment before they choose the right academic discipline to pursue from the various options given to them. ${ }^{6}$ The programme also prepares students psychologically for their prospective fields of study in subsequent years. ${ }^{7.8}$ It was reported that foundation courses for first-year Bachelor of Medicine and Bachelor of Surgery students helped in reducing student anxiety and boosting confidence. ${ }^{9}$ Furthermore, these courses offer intensive training programs to put students'

${ }^{1}$ Department of Basic Sciences, College of Science and Health Professions, King Saud bin Abdulaziz University for Health Sciences, Jeddah, Saudi Arabia; ${ }^{2}$ Department of Microbiology \& Medical Parasitology, Faculty of Medicine, King Abdulaziz University, Jeddah, Saudi Arabia; ${ }^{3}$ Department of Curricula and Methods of Teaching (Mathematics), College of Sciences, King Saud bin Abdulaziz University for Health Sciences, Jeddah, Saudi Arabia; ${ }^{4}$ Department of Family Medicine, Primary Care Centre, Ministry of Health, Jeddah, Saudi Arabia; ${ }^{5}$ College of Dentistry, University of Hail, Hail, Saudi Arabia; ${ }^{6}$ Department of Family Medicine, King Abdulaziz Specialist Hospital, Aljouf, Saudi Arabia; ${ }^{7}$ Medical Education Unit, College of Medicine and Medical Sciences, Arabian Gulf University, Manama, Bahrain; ${ }^{8}$ Medical Education Department, Faculty of Medicine, Suez Canal University, Ismailia, Egypt

"Corresponding Author's e-mail: doctorhani2000@yahoo.com 
professional careers on the right track and enrich their cultural backgrounds. ${ }^{6}$ Among such courses are English language courses, which have a huge impact on student learning and assessment in subsequent college years. ${ }^{10,11}$ Astin's involvement theory indicated that pre-college academic experiences could help students' participation in college experiences. ${ }^{2}$ The role of the preparatory year programme (PYP) can be explained based on this theory.

The PYP at King Abdulaziz University is a oneyear programme that helps students prepare for a full multi-year degree curriculum. It offers a bridge between students' high-school and university-level studies. It has been reported that the existence of the PYP indicates the weaknesses of general education in real-world settings. ${ }^{12,13}$ One established aim of the PYP is to enable new students to explore the academic disciplines of a university and be familiarised with the campus environment. ${ }^{7,14}$ As a result, they are provided with the necessary support to become meaningful contributors, both personally and professionally, at the university and beyond. ${ }^{6}$ Moreover, the preparatory year seeks to help students develop a good relationship with the community through official visits to private and governmental institutions and build student's selfconcept to become an effective person in society.,15

The following is a quote summarising the many goals of the PYP: “The PYP is but a springboard over which ambitious and hardworking students leap energetically, assisted by their experienced faculty, towards their prospective careers, availing themselves of every moment and making full use of all affordable resources." ${ }^{16}$ It is an open invitation for both students and faculty to always be active and on the alert to attain the aspired goals. ${ }^{17,18}$

At King Abdulaziz University, the subjects taught in the PYP include English, biology, chemistry, physics, communication skills, math, statistics and computer skills. These subjects help build a foundation for the scientific track, helping students get into health, engineering and science colleges.

Not too much is known about the overall impact of the PYPs in Saudi universities and on the preparation of health professions education students. Only a few studies have addressed certain aspects of the PYPs in some Saudi universities. Kaliyadan et al. addressed the topic of English language learning in the PYP. ${ }^{10}$ However, to the best of the authors' knowledge, the overall impact of the PYP has not been studied till date. Therefore, this study aimed to explore the perception of students and faculty members of the impact of the preparatory year at King Abdulaziz University on students attending health professions education colleges (medicine, dentistry, pharmacy, nursing and applied medical sciences) in order to make further improvements to the PYP.

\section{Methods}

The study used a descriptive cross-sectional design and was conducted at King Abdulaziz University in Jeddah, Saudi Arabia, between May 2019 and January 2020. Data were collected from both male and female students ( $n=633 ; 261$ males and 372 females) during their first year at medicine, dentistry, applied medical sciences and pharmacy colleges and who had completed the PYP the previous year. Additionally, faculty members who taught PYP students $(n=24)$ were also included in the study.

The instruments used for data collection were as follows: 1) a questionnaire based on a 5-point Likert scale consisting of 30 items used for obtaining student responses developed and validated by Al-Rabia et $\left.a l ;{ }^{19} 2\right)$ structured interviews administered to faculty members to obtain their views on the different aspects of the preparatory year. The structured interviews were based on a list of 10 open-ended questions to explore the view of PYP teachers on the preparatory year [Table 1]. Responses to each question were qualitatively analysed by the authors by reading them critically, linking them to the aim of the study and categorising them according to the three pre-established themes: 1) content of the PYP; 2) value of the preparatory year in getting students ready to study in health professions colleges; and 3) need for a separate track for health professions colleges.

Quantitative data were analysed using the Statistical Package for the Social Sciences (SPSS), Version 24.0 (IBM Corp., Chicago, Illinois, USA). Descriptive statistics were applied and a $P$ value of $<0.05$ was considered statistically significant. Qualitative data (viewpoints of faculty members) were analysed and thematic descriptions were applied to the collected data. Conversations were recorded by the authors; subsequently, the recordings were transcribed and assessed. Data relevant to the pre-established themes were taken into consideration in the analysis.

This study is part of a research project approved by the Research Ethics Committee of the Faculty of Medicine, King Abdulaziz University. Verbal consent was obtained from all participants in this study.

\section{Results}

The study was conducted on a sample of 633 students (response rate: $88.3 \%$ ) from different health professions education colleges at King Abdulaziz 
University and faculty members who taught students in their preparatory year of university. Approximately half of the study's sample agreed that the preparatory year made them self-confident (49.2\%) and reinforced their discipline (46.9\%). Less than two-thirds agreed that the preparatory year reinforced their sense of responsibility and helped them adapt to the university educational environment $(60.6 \%$ and $64.3 \%$, respectively). Conversely, more than half of them (58.5\%) disagreed that the preparatory year classes helped them select their majors and more than half (57.2\%) disagreed that the preparatory year prepared them for their major classes [Table 2].

Nearly two-thirds (64.8\%) of the students disagreed that the preparatory year provided opportunities to engage in activities that developed their various personal skills (e.g. social, physical, cultural and creative). More than half of them disagreed that the faculty motivated them to develop their creative and innovative abilities (56.4\%), the academic counsellor was helpful (58.5\%), the interaction with the academic counsellor was adequate and fruitful (57.7\%) and teaching was interactive rather than spoon-fed (53.4\%). Regarding the ease of communication with faculty, $40.6 \%$ answered affirmatively, approximately a quarter of them $(24.5 \%)$ were neutral and one-third (34.9\%) disagreed [Table 2]. In general, the mean scores of student responses were low, except for ease of communication with faculty, which was a bit higher.

Greater percentages of the sample agreed that the assessment tasks were appropriate (45.7\%), adequate awareness sessions were planned for newcomers (45.7\%), student guidebooks were informative (55.8\%), teaching timetables were set appropriately (49.7\%) and the academic affair services were easily accessible (41.4\%). On the other hand, less than one-third of them (28.9\%) agreed that student support services were adequate. Almost two-thirds of the students (63.5\%) agreed with the appropriateness of the available facilities such as the library, computers, data shows and smart board. While approximately half of them (45.6\%) agreed with the appropriateness of the resting areas designed for students, more than half of the students (56.4\%) disagreed with the suitability of food-purchasing areas for students [Table 2].

Approximately half of the students agreed that after the preparatory year, they had confidence in their abilities to research information (51.9\%), their thinking skills had improved (46.6\%), their computer skills had become more sophisticated (46.1\%) and they could access and use learning resources (53.5\%). Notably, the percentages of people agreeing that their research and scientific writing skills had improved and

those who disagreed were more or less similar to each other [Table 2].

In all cases, however, it could not be assumed that these changes in the different skills were caused by the involvement in the PYP as there could have been some other confounding factors.

There were statistically significant differences among male students from different colleges in their responses to different individual factors studied as part of the questionnaire $(P<0.05)$. However, there was no statistically significant difference among male students of different colleges in terms of their perception of the overall effect of the preparatory year $(\mathrm{F}=2.05 ; P=$ 0.108) [Table 3].

Statistically significant differences appeared between pharmacy and dentistry colleges with regard to the following factors: 'university conduct,' 'administrative and regulatory matters' and 'general perception after completing the preparatory year'. All the differences were due to the higher means scores with regard to the College of Pharmacy, specifically. This indicated that there was a bigger effect of the preparatory year on male pharmacy students than that on male dentistry students [Table 4].

Table 1: Open-ended questions exploring the views of preparatory year programme teachers on the preparatory year

No.

1 What do you think about the preparatory year in terms of its content?

2 What do you think about the preparatory year in terms of its usefulness for health professions education students?

3 Do you think that the preparatory year, in its current shape, would help in preparing students to join a health professions college? Why/Why not?

4. In your opinion, what are the subjects in the preparatory year that the health professions students need not study?

5 In your opinion, what are the subjects that are required to be included in the preparatory year program?

6 Do you think that students of health professions colleges need a separate pathway for health professions studies in the preparatory year? Why/ Why not?

$7 \quad$ Do you think that the relative weight of the grades students gain in their preparatory year is suitable as one of the admission criteria in health professions colleges? Why/why not?

8 In your opinion, what are the most important challenges during the preparatory year?

9 What are your suggestions for reforming the preparatory year?

10 Generally, what is your evaluation of the preparatory year? 
Table 2: Student responses to the questionnaire evaluating the perceptions of the impact of the preparatory year programme at health professions education colleges of King Abdulaziz University, Jeddah, Saudi Arabia $(\mathrm{N}=633)^{*}$

\begin{tabular}{|c|c|c|c|c|}
\hline \multirow[t]{2}{*}{ No. } & \multirow[t]{2}{*}{ Statement } & \multicolumn{3}{|c|}{ n (\%) } \\
\hline & & Disagree & Neutral & Agree \\
\hline \multicolumn{5}{|c|}{ University conduct } \\
\hline 1 & $\begin{array}{l}\text { The preparatory } \\
\text { year made me self- } \\
\text { confident }\end{array}$ & $\begin{array}{c}204 \\
(32.2)\end{array}$ & $\begin{array}{c}117 \\
(18.5)\end{array}$ & $\begin{array}{c}312 \\
(49.2)\end{array}$ \\
\hline 2 & $\begin{array}{l}\text { The preparatory } \\
\text { year reinforced my } \\
\text { discipline }\end{array}$ & $\begin{array}{c}217 \\
(34.3)\end{array}$ & $\begin{array}{c}119 \\
(18.8)\end{array}$ & $\begin{array}{c}297 \\
(46.9)\end{array}$ \\
\hline 3 & $\begin{array}{l}\text { The preparatory year } \\
\text { reinforced my sense } \\
\text { of responsibility }\end{array}$ & $\begin{array}{c}157 \\
(24.8)\end{array}$ & $93(14.7)$ & $\begin{array}{c}383 \\
(60.5)\end{array}$ \\
\hline 4 & $\begin{array}{l}\text { The preparatory year } \\
\text { helped me adapt } \\
\text { to the university } \\
\text { educational } \\
\text { environment }\end{array}$ & $\begin{array}{c}139 \\
(22.0)\end{array}$ & $87(13.7)$ & $\begin{array}{c}407 \\
(64.3)\end{array}$ \\
\hline 5 & $\begin{array}{l}\text { Preparatory year } \\
\text { classes helped me } \\
\text { select my major }\end{array}$ & $\begin{array}{c}370 \\
(58.5)\end{array}$ & $\begin{array}{c}103 \\
(16.3)\end{array}$ & $\begin{array}{c}160 \\
(25.3)\end{array}$ \\
\hline 6 & $\begin{array}{l}\text { I feel that the } \\
\text { preparatory year } \\
\text { classes prepared me } \\
\text { well for my major's } \\
\text { classes. }\end{array}$ & $\begin{array}{c}362 \\
(57.2)\end{array}$ & $\begin{array}{c}103 \\
(16.3)\end{array}$ & $\begin{array}{c}168 \\
(26.5)\end{array}$ \\
\hline \multicolumn{5}{|c|}{ Perception of faculty, teaching and assessment } \\
\hline 7 & $\begin{array}{l}\text { The preparatory year } \\
\text { provided activities } \\
\text { that developed my } \\
\text { various personal skills } \\
\text { (e.g., social, physical, } \\
\text { cultural, creative) }\end{array}$ & $\begin{array}{c}410 \\
(64.8)\end{array}$ & $\begin{array}{c}110 \\
(17.4)\end{array}$ & $\begin{array}{c}113 \\
(17.9)\end{array}$ \\
\hline 8 & $\begin{array}{l}\text { Communication with } \\
\text { faculty was easy }\end{array}$ & $\begin{array}{c}221 \\
(34.9)\end{array}$ & $\begin{array}{c}155 \\
(24.5)\end{array}$ & $\begin{array}{c}257 \\
(40.6)\end{array}$ \\
\hline 9 & $\begin{array}{l}\text { The faculty motivated } \\
\text { me to develop } \\
\text { my creative and } \\
\text { innovative abilities }\end{array}$ & $\begin{array}{c}357 \\
(56.4)\end{array}$ & $\begin{array}{c}163 \\
(25.8)\end{array}$ & $\begin{array}{c}113 \\
(17.9)\end{array}$ \\
\hline 10 & $\begin{array}{l}\text { The faculty showed } \\
\text { attributes of } \\
\text { professionalism (e.g. } \\
\text { honesty, integrity, } \\
\text { altruism, etc. }\end{array}$ & $\begin{array}{c}285 \\
(45.0)\end{array}$ & $\begin{array}{c}184 \\
(29.1)\end{array}$ & $\begin{array}{c}164 \\
(25.9)\end{array}$ \\
\hline 11 & $\begin{array}{l}\text { My academic } \\
\text { counsellor was } \\
\text { helpful }\end{array}$ & $\begin{array}{c}370 \\
(58.5)\end{array}$ & $\begin{array}{c}149 \\
(23.5)\end{array}$ & $\begin{array}{c}114 \\
(18.3)\end{array}$ \\
\hline 12 & $\begin{array}{l}\text { Interactions with my } \\
\text { academic counsellor } \\
\text { were adequate and } \\
\text { fruitful }\end{array}$ & $\begin{array}{c}365 \\
(57.7)\end{array}$ & $\begin{array}{c}161 \\
(25.4)\end{array}$ & $\begin{array}{c}107 \\
(16.9)\end{array}$ \\
\hline 13 & $\begin{array}{l}\text { Teaching was } \\
\text { interactive rather } \\
\text { than spoon-feeding }\end{array}$ & $\begin{array}{c}338 \\
(53.4)\end{array}$ & $\begin{array}{c}164 \\
(25.9)\end{array}$ & $\begin{array}{c}131 \\
(20.7)\end{array}$ \\
\hline 14 & $\begin{array}{l}\text { Feedback on student } \\
\text { assessment was } \\
\text { helpful }\end{array}$ & $\begin{array}{c}235 \\
(37.1)\end{array}$ & $\begin{array}{c}208 \\
(32.9)\end{array}$ & $\begin{array}{c}190 \\
(30.0)\end{array}$ \\
\hline \multicolumn{5}{|c|}{ Administrative and regulatory matters } \\
\hline 15 & $\begin{array}{l}\text { Student support } \\
\text { services (i.e. } \\
\text { academic, social, } \\
\text { psychological) were } \\
\text { adequate }\end{array}$ & $\begin{array}{c}235 \\
(37.1)\end{array}$ & $\begin{array}{c}215 \\
(34.0)\end{array}$ & $\begin{array}{c}183 \\
(28.9)\end{array}$ \\
\hline
\end{tabular}

\begin{tabular}{|c|c|c|c|c|}
\hline 16 & $\begin{array}{l}\text { Assessment tasks } \\
\text { (e.g. tests, projects, } \\
\text { assignments) were } \\
\text { appropriate }\end{array}$ & $\begin{array}{c}217 \\
(34.3)\end{array}$ & $\begin{array}{c}127 \\
(20.1)\end{array}$ & $\begin{array}{c}289 \\
(45.7)\end{array}$ \\
\hline 17 & $\begin{array}{l}\text { Introductory } \\
\text { (awareness) sessions } \\
\text { were planned with } \\
\text { the newcomer } \\
\text { students }\end{array}$ & $\begin{array}{c}200 \\
(31.6)\end{array}$ & $\begin{array}{c}144 \\
(22.7)\end{array}$ & $\begin{array}{c}289 \\
(45.7)\end{array}$ \\
\hline 18 & $\begin{array}{l}\text { Students' guidebook } \\
\text { was informative and } \\
\text { adequate }\end{array}$ & $\begin{array}{c}149 \\
(23.5)\end{array}$ & $\begin{array}{c}131 \\
(20.7)\end{array}$ & $\begin{array}{c}353 \\
(55.8)\end{array}$ \\
\hline 19 & $\begin{array}{l}\text { Teaching timetables } \\
\text { were set out } \\
\text { appropriately }\end{array}$ & $\begin{array}{c}197 \\
(31.1)\end{array}$ & $\begin{array}{c}122 \\
(19.3)\end{array}$ & $\begin{array}{c}314 \\
(49.6)\end{array}$ \\
\hline 20 & $\begin{array}{l}\text { Academic affairs } \\
\text { services (e.g. } \\
\text { withdrawal, } \\
\text { course additions } \\
\text { and deletions, } \\
\text { postponing, excuses) } \\
\text { were easily accessible }\end{array}$ & $\begin{array}{c}185 \\
(29.2)\end{array}$ & $\begin{array}{c}186 \\
(29.4)\end{array}$ & $\begin{array}{c}262 \\
(41.4)\end{array}$ \\
\hline \multicolumn{5}{|c|}{ Facilities and services } \\
\hline 21 & $\begin{array}{l}\text { The facilities (e.g. } \\
\text { library, computers, } \\
\text { data-shows, smart } \\
\text { boards) were } \\
\text { appropriate }\end{array}$ & $\begin{array}{c}119 \\
(18.8)\end{array}$ & $\begin{array}{c}112 \\
(17.7)\end{array}$ & $\begin{array}{c}402 \\
(63.5)\end{array}$ \\
\hline 22 & $\begin{array}{l}\text { Places designated } \\
\text { for student rest } \\
\text { and sitting were } \\
\text { appropriate }\end{array}$ & $\begin{array}{c}219 \\
(34.6)\end{array}$ & $\begin{array}{c}125 \\
(19.8)\end{array}$ & $\begin{array}{c}289 \\
(45.7)\end{array}$ \\
\hline 23 & $\begin{array}{l}\text { Food purchasing } \\
\text { areas were suitable } \\
\text { for all students }\end{array}$ & $\begin{array}{c}357 \\
(56.4)\end{array}$ & $\begin{array}{c}100 \\
(15.8)\end{array}$ & $\begin{array}{c}176 \\
(27.8)\end{array}$ \\
\hline
\end{tabular}

General perception after completing the preparatory year

\begin{tabular}{|c|c|c|c|c|}
\hline 24 & $\begin{array}{l}\text { I have confidence in } \\
\text { my ability to research } \\
\text { information }\end{array}$ & $\begin{array}{c}149 \\
(23.5)\end{array}$ & $\begin{array}{c}156 \\
(24.6)\end{array}$ & $\begin{array}{c}328 \\
(51.8)\end{array}$ \\
\hline 25 & $\begin{array}{l}\text { My thinking skills } \\
\text { (e.g. interpretation, } \\
\text { analysis, inference, } \\
\text { explanation) have } \\
\text { improved }\end{array}$ & $\begin{array}{c}193 \\
(30.5)\end{array}$ & $\begin{array}{c}145 \\
(22.9)\end{array}$ & $\begin{array}{c}295 \\
(46.6)\end{array}$ \\
\hline 26 & $\begin{array}{l}\text { My computer } \\
\text { skills became more } \\
\text { sophisticated }\end{array}$ & $\begin{array}{c}208 \\
(32.9)\end{array}$ & $\begin{array}{c}133 \\
(21.0)\end{array}$ & $\begin{array}{c}292 \\
(46.1)\end{array}$ \\
\hline 27 & $\begin{array}{l}\text { My research skills } \\
\text { became more } \\
\text { sophisticated }\end{array}$ & $\begin{array}{c}241 \\
(38.1)\end{array}$ & $\begin{array}{c}178 \\
(28.1)\end{array}$ & $\begin{array}{c}214 \\
(33.8)\end{array}$ \\
\hline 28 & $\begin{array}{l}\text { My scientific writing } \\
\text { skills became more } \\
\text { sophisticated }\end{array}$ & $\begin{array}{c}254 \\
(40.1)\end{array}$ & $\begin{array}{c}157 \\
(24.8)\end{array}$ & $\begin{array}{c}222 \\
(35.1)\end{array}$ \\
\hline 29 & $\begin{array}{l}\text { I can access and use } \\
\text { learning resources } \\
\text { (e.g. library and } \\
\text { internet resources) }\end{array}$ & $\begin{array}{c}172 \\
(27.2)\end{array}$ & $\begin{array}{c}122 \\
(19.3)\end{array}$ & $\begin{array}{c}339 \\
(53.6)\end{array}$ \\
\hline 30 & $\begin{array}{l}\text { My skills in applying } \\
\text { knowledge have } \\
\text { improved }\end{array}$ & $\begin{array}{c}200 \\
(31.6)\end{array}$ & $\begin{array}{c}178 \\
(28.1)\end{array}$ & $\begin{array}{c}255 \\
(40.3)\end{array}$ \\
\hline
\end{tabular}

"The 5-point scale was collapsed to 3 points for easy interpretation of results and increasing cell sample size. Both "Agree" and "Strongly Agree" were considered as "Agree" while both "Disagree" and "Strongly Disagree" were considered as "Disagree". 
Table 3: College-wise mean scores on the factors of the preparatory year programme perception questionnaire for male students attending King Abdulaziz University, Jeddah, Saudi Arabia $(n=261)$

\begin{tabular}{|c|c|c|c|c|c|}
\hline Factors $^{\dagger}$ & $\begin{array}{l}\text { Sum of } \\
\text { squares }\end{array}$ & df & $\begin{array}{l}\text { Mean } \\
\text { square }\end{array}$ & $\mathbf{F}$ & $\begin{array}{l}P \\
\text { value }^{*}\end{array}$ \\
\hline $\begin{array}{l}\text { University } \\
\text { conduct }\end{array}$ & 621.94 & 3 & 207.31 & 3.92 & 0.009 \\
\hline $\begin{array}{l}\text { Perception } \\
\text { of faculty, } \\
\text { teaching and } \\
\text { assessment }\end{array}$ & 706.27 & 3 & 235.42 & 4.54 & 0.004 \\
\hline $\begin{array}{l}\text { Administrative } \\
\text { and regulatory } \\
\text { matters }\end{array}$ & 608.12 & 3 & 202.71 & 5.30 & 0.001 \\
\hline $\begin{array}{l}\text { Facilities and } \\
\text { services }\end{array}$ & 641.24 & 3 & 213.75 & 7.09 & $<0.001$ \\
\hline $\begin{array}{l}\text { General } \\
\text { perception } \\
\text { after } \\
\text { completing the } \\
\text { preparatory } \\
\text { year }\end{array}$ & 100.70 & 3 & 33.57 & 3.14 & 0.026 \\
\hline $\begin{array}{l}\text { Sum of } \\
\text { the whole } \\
\text { questionnaire }\end{array}$ & 3777.07 & 3 & 1259.02 & 2.05 & 0.108 \\
\hline
\end{tabular}

There were statistically significant differences between female students from different colleges with regard to their responses to different individual factors of the questionnaire $(P<0.05)$, except for the 'facilities and services' factor. Furthermore, there was also a statistically significant difference among female students from different colleges in their perception of the overall effect of the preparatory year $(\mathrm{F}=3.24 ; \mathrm{P}=$ 0.012) [Table 5].
There were differences between female students of dentistry and medicine with respect to 'university conduct', 'perception of faculty, teaching and assessment' and the sum of the whole questionnaire. Moreover, there were differences between female students of dentistry and nursing in a few factors, namely 'perception of faculty, teaching and assessment', 'general perception after completing the preparatory year', and the sum of the whole questionnaire. Furthermore, there were differences between female students of dentistry and pharmacy in terms of factors such as 'general perception after completing the preparatory year' and the sum of the whole questionnaire. The perception of female dentistry students appears across all of the mentioned observations indicating that there was a greater effect of the preparatory year on female dentistry students than those from the colleges of medicine, pharmacy and nursing [Table 6].

\section{THEME 1: CONTENT OF THE PREPARATORY YEAR PROGRAMME}

The success of planning for the PYP requires careful consideration of the content of the courses offered to students. According to the 24 included faculty members, revision and update of such courses with the knowledge and skills needed by the students are required. One faculty member indicated, "Arabic language is one of the subjects taught to the students in the preparatory year. It is good. However, in the Arabic language, the students study only some irrelevant topics to their health professions studies." Another member stated, "some topics studied by the students in biology are outdated. I think we need to pay more attention to the specific and up-to-date medical sciences like molecular biology"

Table 4: College-wise differences in responses to the preparatory year programme questionnaire for male students attending King Abdulaziz University, Jeddah, Saudi Arabia ( $\mathrm{n}=261$ )

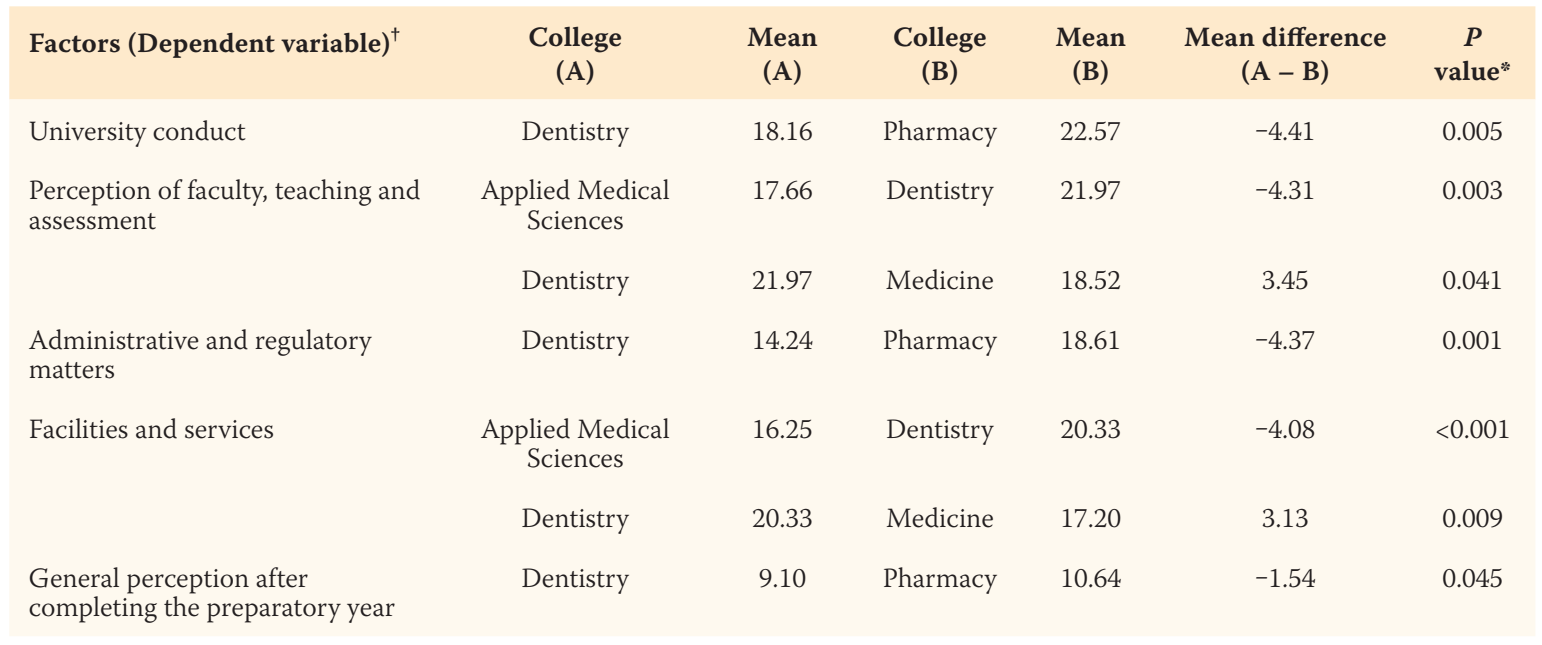

"Statistically significant at $P<0.05$.

${ }^{+}$Means determined using Tukey's range test. 
THEME 2: VALUE OF THE PYP IN QUALIFYING STUDENTS TO STUDY IN HEALTH PROFESSIONS COLLEGES

The PYP consists of general subjects that are similar to those studied at the high school level. The content of subjects related to health professions studies (i.e. biology, chemistry and physics courses) is small and general in nature. For preparing health professions students, such content should be strengthened and made up-to-date. This was clearly indicated in the responses of some of the faculty members interviewed. One of the members indicated, "most of the courses in the preparatory year program are general courses that don't help prepare the students to study in the health professions colleges. Attention should be paid to such courses to make them relevant to the goal of that program." A faculty member also mentioned, "we are preparing students to study medical sciences so it is better to give them the background knowledge for such sciences in the preparatory year, and no need to waste their time in studying irrelevant content."

\section{THEME 3: NEED FOR A SEPARATE TRACK FOR HEALTH PROFESSIONS COLLEGES}

In general, faculty members felt the need for a separate track in the preparatory year for health professions colleges. They claimed that the presence of a separate track would provide a better chance to include subjects that were directly related to the study of health professions (such as molecular sciences, genetics, medical terminology and English for medical purposes). A faculty member indicated, "a separate track for health professions students would be a
Table 5: College-wise mean scores on the factors of the preparatory year programme perception questionnaire for female students attending King Abdulaziz University, Jeddah, Saudi Arabia $(\mathrm{n}=372)$

\begin{tabular}{|c|c|c|c|c|c|}
\hline Factors $^{\dagger}$ & $\begin{array}{l}\text { Sum of } \\
\text { squares }\end{array}$ & df & $\begin{array}{l}\text { Mean } \\
\text { square }\end{array}$ & F & $\begin{array}{c}P \\
\text { value }^{*}\end{array}$ \\
\hline $\begin{array}{l}\text { University } \\
\text { conduct }\end{array}$ & 406.43 & 4 & 101.61 & 2.59 & 0.037 \\
\hline $\begin{array}{l}\text { Perception } \\
\text { of faculty, } \\
\text { teaching and } \\
\text { assessment }\end{array}$ & 546.09 & 4 & 136.52 & 3.59 & 0.007 \\
\hline $\begin{array}{l}\text { Administrative } \\
\text { and regulatory } \\
\text { matters }\end{array}$ & 416.50 & 4 & 104.13 & 3.37 & 0.010 \\
\hline $\begin{array}{l}\text { Facilities and } \\
\text { services }\end{array}$ & 101.64 & 4 & 25.41 & 1.16 & 0.340 \\
\hline $\begin{array}{l}\text { General } \\
\text { perception } \\
\text { after } \\
\text { completing the } \\
\text { preparatory } \\
\text { year }\end{array}$ & 163.89 & 4 & 40.97 & 4.86 & 0.001 \\
\hline $\begin{array}{l}\text { Sum of } \\
\text { the whole } \\
\text { questionnaire }\end{array}$ & 5237.22 & 4 & 1309.31 & 3.24 & 0.012 \\
\hline
\end{tabular}

great idea that will better help them be prepared for further studies in that sensitive field of study." Another member also stated, "having a separate track for health professions students will help avoid wasting the time of the students in studying irrelevant content that will not fit well in their preparation for studying in health professions education colleges."

Table 6: College-wise differences in responses to the preparatory year programme questionnaire for female students attending King Abdulaziz University, Jeddah, Saudi Arabia ( $\mathrm{n}=372)$

\begin{tabular}{|c|c|c|c|c|c|c|}
\hline Factor (Dependent variable) ${ }^{\dagger}$ & $\begin{array}{l}\text { College } \\
\text { (A) }\end{array}$ & $\begin{array}{l}\text { Mean } \\
\text { (A) }\end{array}$ & $\begin{array}{l}\text { College } \\
\text { (B) }\end{array}$ & $\begin{array}{c}\text { Mean } \\
\text { (B) }\end{array}$ & $\begin{array}{l}\text { Mean difference } \\
\qquad(\mathrm{A}-\mathrm{B})\end{array}$ & $\begin{array}{c}P \\
\text { value }^{*}\end{array}$ \\
\hline University conduct & Dentistry & 25.34 & Medicine & 21.98 & 3.36 & 0.022 \\
\hline \multirow{2}{*}{$\begin{array}{l}\text { Perception of faculty, teaching and } \\
\text { assessment }\end{array}$} & Dentistry & 23.40 & Medicine & 19.71 & 3.69 & 0.007 \\
\hline & Dentistry & 23.40 & Nursing & 20.43 & 2.97 & 0.053 \\
\hline Administrative and regulatory matters & $\begin{array}{l}\text { Applied } \\
\text { Medical } \\
\text { Sciences }\end{array}$ & 21.05 & Nursing & 18.16 & 2.89 & 0.007 \\
\hline \multirow{2}{*}{$\begin{array}{l}\text { General perception after completing the } \\
\text { preparatory year }\end{array}$} & Dentistry & 10.23 & Pharmacy & 7.82 & 2.41 & $<0.001$ \\
\hline & Dentistry & 10.23 & Nursing & 8.39 & 1.84 & 0.004 \\
\hline \multirow[t]{3}{*}{ Sum of the whole questionnaire } & Dentistry & 99.23 & Medicine & 89.30 & 9.93 & 0.043 \\
\hline & Dentistry & 99.23 & Pharmacy & 87.41 & 11.82 & 0.031 \\
\hline & Dentistry & 99.23 & Nursing & 89.41 & 9.82 & 0.048 \\
\hline
\end{tabular}




\section{Discussion}

A primary principle upon which the PYP was originally based is that it is an important transitional stage between high school and university that prepares students for a new academic context by alleviating the anxiety of studying in a university, giving them a solid linguistic base of the foreign language used for instruction and helping them shift from adolescent education to adult learning. ${ }^{10,21,22}$ However, results from the current study indicate that the impact of the PYP on the students, in general, was weak. These findings are similar to those found by Alkathiri in his evaluation of the PYP. ${ }^{20}$

Although teaching, assessment and student support are the most important activities in the PYP and as such, special attention should be given to them, it is clear from the student responses that they perceive teaching, faculty and assessment negatively and are unsatisfied. As stated by Alkathiri, it seems to be a big challenge to attract and train qualified faculty for the success of the PYP. ${ }^{20}$ Zeller and Zlotkowski argued that universities should strive to appeal to qualified faculty for the preparatory year, else the effectiveness of the programme may be questioned continuously, which will be reflected in the impact on the quality of the outputs of the preparatory year. This, in turn, may affect the review of the importance of such programmes in the future..$^{23,24}$

Students in the preparatory year are in need of guidance and assistance. Student support services are one of the most important services these students need to support their transition into university life. To offer good support to these students, policies and practices should be in place and be consistent with academic policies. Starting from admissions to the end of the year, preparatory year officials must regard clear instructions, effective communication and support for the achievement of all means of success as their responsibilities. ${ }^{12,25,26}$

For the success of any academic curriculum, suitable and enough educational facilities should be made available to students. ${ }^{27}$ In a similar study, Alghamdi reported an average level of satisfaction of preparatory year students with the services offered by the university. ${ }^{28}$ Although cafeterias and food purchasing areas are not educational facilities, they are considered to play a very important role in making students' on-campus life easier. Furthermore, the influence of the academic advisor is very important, and as such, their role should be strengthened such that the students can benefit well from it. The academic advisor should be more interactive with the students and help them in different aspects of their lives. This is important as the preparatory year is the first university year for the students and they may feel lost and need much help from their academic advisors. These advisors can orient students to the rules and regulations of the institution and also guide them through the academic processes in the university.

The current study showed that more than half the students did not perceive the teaching process as being interactive. In this regard, the preparatory year faculty members need to make their lectures more interactive and give the students an active role in their learning as adults in order to help them change their mindset from dependent pupils to independent learners. This will lead to the development of students' cognitive skills and help them navigate medical studies at the university that require the use of higher cognitive skills. ${ }^{29}$ Additionally, the preparatory year faculty need to promote creative skills in students by creating a safe learning environment. This could be done by intellectually stimulating the students to discover, develop and use their creative and critical thinking skills..$^{20}$

The mean scores for the female students were greater than those for males across all factors, except the 'general perception after completing the preparatory year' factor, where the mean scores were more favourable for the male students. The differences were statically significant indicating that although female students reported more satisfaction than male students in the preparatory year, the preparatory year was reported to have a greater impact on the latter.

In Saudi Arabian universities, there is a separation between male and female campuses. The faculty within each of these campuses are also different from each other. This is expected to be the primary reason for the differences in mean scores of different factors. The reason behind high scores for females may be that there is a better educational and aesthetic environment on their campus. On the other hand, male students' mean scores were potentially higher on the 'general perception after completing the preparatory year' factor in relation to the other factors as they do not seem to depend mainly on the preparatory. This finding would need further explanatory research.

Regarding the remaining two factors, namely 'perception of faculty, teaching and assessment' and 'facilities and services', the differences appeared between male dentistry students and both male medicine and male applied medical sciences students indicating that there was a greater impact of the preparatory year on male dentistry students than that on medicine and applied medical sciences male students in terms of those two factors. 
Dentistry students (both males and females) perceived the effect of the preparatory year more positively than the students in other health colleges. This might be due to the fact that the former group believed that the subjects they studied in that year (especially physics) benefited them greatly in their dentistry subjects.

Much like any study of this sort, this study has its limitations too. Firstly, the study focused only on a single university. Although King Abdulaziz University is the biggest government university in Saudi Arabia, findings would have been more valuable and generalisable had more universities been included. Secondly, the study regarded students and faculty members as the most important stakeholders when considering participant selection; however, it would have been of great value to also include university officials responsible for the PYP as part of the interviews or via focus groups.

\section{Conclusion}

The impact of the preparatory year on students attending health professions education colleges at King Abdulaziz University was weak. This seemed to be the opinion of both students and faculty members. Additionally, there was no statistically significant difference between males and females. Special courses for health professions students should be included in a year often regarded as being important for a student. The authors recommend further in-depth studies in this field to understand the effect of different components of the preparatory year on students and to formulate recommendations for improvement and reformations for decision-makers.

\section{CONFLICT OF INTEREST}

The authors declare no conflicts of interest.

\section{FUNDING}

No funding was received for this study.

\section{ACKNOWLEDGEMENTS}

The authors would like to thank all the students and faculty members who participated in this study. A special thanks is given to the Deanship of the Preparatory Year at King Abdulaziz University for facilitating this work.

\section{AUTHORS' CONTRIBUTION}

AhA, MA-R and HAt conceptualised the work. FA, MA-R, HAl and HAt prepared the research plan. All authors participated in data collection and analysis. All authors contributed to drafting the manuscript. HAt,
MA-R, NA and AbA edited the final draft. All authors approved the final version of the manuscript.

\section{References}

1. Tinto V. Classrooms as communities. Exploring the educational character of student persistence. J High Educ 1997; 68:599-623. https://doi.org/10.2307/2959965.

2. Astin AW. Student involvement: A developmental theory for higher education. J College Student Devel 1999; 40:518-29.

3. Pascarella E, Terenzini . How College Affects Students: A Third Decade of Research, vol 2. San Francisco: John Wiley \& Sons, 2005.

4. Padgett RD, Goodman KM, Johnson MP, Saichaie K, Umbach PD, Pascarella ET. The impact of college student socialization, social class, and race on need for cognition. New Directions Institutional Res 2010; 145:99-111. https://doi.org/10.1002/ir.324.

5. Price L. Modelling factors for predicting student learning outcomes in higher education. In: Gijbels D, Donche V, Richardson JTE, Vermunt JD, Eds. Learning Patterns in Higher Education: Dimensions and Research Perspectives. Abingdon: Routledge, 2014, pp. 56-77.

6. Adelman C. The toolbox revisited: Paths to degree completion from high school through college. From: http://www2.ed.gov/ rschstat/research/pubs/toolboxrevisit/toolbox.pdf Accessed: Jul 2020.

7. Barefoot BO. Current institutional practices in the first college year. In: Upcraft ML, Gardner JN, Barefoot BO, Eds. Challenging and Supporting the First Year Student: A Handbook for Improving the First Year of College, 1st ed. San Francisco: Jossey-Bass, 2005, pp. 47-63.

8. Bettinger E, Boatman A, Long BT. Student supports: Developmental education and other academic programs. Future Child 2013; 23:93-115. https://doi.org/10.1353/foc.2013.0003.

9. Patel J, Akhani P. A study of perception of first-year MBBS students toward orientation program and foundation course at entry level. Nat J Physiol Pharm Pharmacol 2017; 7:920-3. https//doi.org/10.5455/njppp.2017.7.0412301052017.

10. Kaliyadan F, Thalamkandathil N, Parupalli SR, Amin TT, Balaha MH, $\mathrm{Al} \mathrm{Bu} \mathrm{Ali} \mathrm{WH.} \mathrm{English} \mathrm{language} \mathrm{proficiency} \mathrm{and} \mathrm{academic}$ performance: A study of a medical preparatory year program in Saudi Arabia. Avicenna J Med 2015; 5:140-4. https://doi. org/10.4103/2231-0770.165126.

11. Mirgani Z, Shantakumari N, Hassan I. Predictors of student performance in foundation year of medical school. Sys Rev Pharm 2020; 11:201-5.

12. Hart Research Associates. It takes more than a major: Employer priorities for college learning and student success. From: https://www.aacu.org/research/it-takes-more-than-a-majoremployer-priorities-for-college-learning-and-student-success Accessed: Nov 2020

13. Baum S, Kurose C, McPherson M. An overview of American higher education. Future Child 2013; 23:17-39. https://doi. org/10.1353/foc.2013.0008.

14. Edmunds JA., Bernstein L, Unlu F, Glennie EJ, Willse JT, Smith A, et al. Expanding the start of the college pipeline: Ninth-grade findings from an experimental study of the impact of the early college high school model. J Res Educ Effective 2012; 5:136-59. https://doi.org/10.1080/19345747.2012.656182.

15. Howell JS, Kurlaender M, Grodsky EE. Postsecondary preparation and remediation: Examining the effect of the Early Assessment Program at California State University. J Policy Anal Manag 2010; 29:726-48. https://doi.org/10.1002/pam.20526.

16. Preparatory Year Handbook. Imam Abdulrahman Bin Faisal University, Dammam, Saudi Arabia. From: https://www.iau.edu. $\mathrm{sa} /$ sites/default/files/resources/prepyearhandbooknewadddes. compressed.pdf Accessed: Nov 2020. 
17. Barefoot BO, Griffin BQ, Koch AK. Enhancing student success and retention throughout undergraduate education: A national survey. From:https://static1.squarespace.com/static/59b0c486d 2 b 857 fc 86 d 09 a e e / t / 59 b a d 33412 abd 988 ad 8 4d697/1505415990531/JNGInational_survey_web.pdf Accessed: Nov 2020

18. Barnett EA, Bork RH, Mayer AK, Pretlow J, Washington HD, Weiss MJ. Bridging the Gap: An Impact Study of Eight Developmental Summer Bridge Programs in Texas. New York: Columbia University, National Center for Postsecondary Research, 2012.

19. Al-Rabia M, Shawwa LA, Gouda E, Aldarmahi A, Asfour $\mathrm{H}$, Atwa $H$. Validation of a questionnaire evaluating the effect of a preparatory year on qualifying students for studying at health professions education faculties. Afr J Health Prof Educ 2021; 13:72-6. https://doi.org/10.7196/AJHPE.2021.v13i1.1273.

20. Alkathiri N. Preparatory year (first year experience). Saudi High Educ 2014; 11:65-70.

21. Al Asmari A. A comparative analysis of preparatory year students' FL anxiety. Int J English Linguistics 2015; 5:50-62. https://doi.org/10.5539/ijel.v5n4p50.

22. De Clercq1 M, Galand B, Frenay M. Transition from high school to university: A person-centered approach to academic achievement. Eur J Psychol Educ 2017; 32:39-59. https://doi. org/10.1007/s10212-016-0298-5.
23. Zeller WJ. First-year student living environments. In: Upcraft ML, Gardner JN, Barefoot BO, Eds. Challenging and Supporting the First-year Student: A Handbook for Improving the First Year of College. San Francisco: Jossey-Bass, 2005, pp. 410-27.

24. Zlotkowski E. Service learning and the first-year student. In: Upcraft ML, Gardner JN, Barefoot BO, Eds. Challenging and Supporting the First-year Student: A Handbook for Improving the First Year of College. San Francisco: Jossey-Bass, 2005.

25. Alexander JS, Gardner J. Beyond retention: A comprehensive approach to the first college year. From: https://www.dropbox. $\mathrm{com} / \mathrm{s} / \mathrm{xltxyxhxu0wsctt/Beyond-Retention-A-comprehensive-}$ approach-to-FY.pdf Accessed: Nov 2020.

26. Alaqeeli S. The preparatory year: Global perspectives and local practices. Saudi J High Educ 2014; 11:45-64.

27. Kern DE, Thomas PA, Hughes MT. Curriculum Development for Medical Education: A Six-Step Approach, 2nd ed. Baltimore: Johns Hopkins University Press, 2009.

28. Alghamdi OS. Satisfaction of preparatory year students with university services. World J Educ 2015; 5:117-29. https://doi. org/10.5430/wje.v5n5p117.

29. Duggan PM, Palmer E, Devitt P. Electronic voting to encourage interactive lectures: A randomized trial. BMC Med Educ 2007; 7:25. https://doi.org/10.1186/1472-6920-7-25. 